\title{
AN ANALYSIS OF JOKOWI'S POLICY IN REFUSING THE RETURN OF FORMER ISIS FOREIGN TERRORIST FIGHTERS INDONESIAN CITIZENS
}

\author{
Irfan Amir \\ Lecturer at State Institute of Islamic Studies (IAIN) Bone \\ Email:irfanamir066@gmail.com
}

\begin{abstract}
Industry 4.0 which is supported by the concept of the internet of think has influenced the pattern of indoctrination of radical-terrorism groups. Based on the results of the study, after the declaration until the collapse of the Islamic State of Iran and Syria (ISIS) there were at least 689 foreign terrorist fighters who came from Indonesia and hoped to be repatriated to the country. However, because of security considerations, President Joko Widodo firmly refused. To address this issue, the author conducts normative-empirical legal research using library research methods. The results showed that Indonesian citizens involved in organized international crimes such as ISIS can be banned from returning to Indonesia on a legal basis using Article 98 Paragraph 1 of Law No. 6 of 2011 concerning Immigration and Article 263 Paragraph 2 letter (a) Government Regulation No. 21 of 2013 concerning Regulations for Implementing the Immigration Law. Besides, terrorist sleep cells of ISIS in the country can at any time carry out suicide bomb attacks as a signal given by their group. As an ideological network, these terrorism sleep cells are clandestine and begin to involve women and children as suicide bombers.
\end{abstract}

Industri 4.0 yang ditopang oleh konsep internet of thinktelah mempengaruhi pola indoktrinisasi kelompok radikal-terorism. Berdasarkan hasil penelitian, pasca dideklrasikannya hingga runtuhnya kejayaan Islamic State of Iran and Syria/Negara Islam Irak dan Suriah (ISIS) sedikitnyaterdapat 689 foreign terrorist fighter yang berasal dari Indonesia dan berharap dapat dipulangkan ke tanah air.Namun, dengan pertimbangan keamanan Presiden Joko Widodo, tegas menolaknya.Untuk menelah persoalan ini, penulis melakukan penelitian hukum normtif-empiris dengan menggunakan metode penelitian kepustakaan (library research). Hasil penelitian menunjukkan bahwa WNI yang terlibat dalam kejahatan internasional terorganisir seperti ISIS dapat dicekal masuk kembali ke Indonesia dengan dasar hukum menggunakan Pasal 98 Ayat 1 Undang-Undang No. 6 Tahun 2011 tentang Keimigrasian serta Pasal 263 Ayat 2 huruf (a) PP No. 21 Tahun 2013 tentang Peraturan Pelaksanaan UU Keimigrasian. Selain dari pada itu, sel-sel tidur terorisme ISIS di dalam negeri setiap waktu dapat melancarkan serangan bom bunuh diri sebagaimana sinyal yang diberikan oleh kelompoknya.Sebagai jaringan ideologis, 
sel-sel tidur terorisme ini sifatnya klandestin dan mulai melibatkan perempuan beserta anak-anak sebagai pelaku bom bunuh diri.

Keywords: Foreign Terrorist Fighter; Terrorism; ISIS.

\section{INTRODUCTION}

Information technology that is developing so rapidly and sophisticated has become one of the main characteristics of the industrial revolution 4.0 era and of course has had a significant impact on the patterns of interaction of global society, including in Indonesia. When examined further, that one of the supporting technologies of the development of the industrial revolution $4.0^{1}$ is the Internet of Things (IoT), which is the idea that carries the concept of expanding the benefits of internet connectivity that is connected continuously to reach various groups throughout the region both in urban and rural areas. Thus, from the concept of the internet of things it also provides an opportunity for anyone to freely spread certain ideologies or ideologies that could potentially cause various conflicts in the country to culminate in the context of national disintegration. Then the question is what about Indonesia.

Indonesia as an archipelagic country which is inhabited by people from various tribes, races and religions is certainly easily infiltrated by intolerant issues and ridden by radical-terrorism groups. As an illustration, based on data from the Global Terrorism Index in 2019, Indonesia became one of the countries affected by terrorism, ranking 35th out of 138 affected countries, while the first rank was occupied by Afghanistan. ${ }^{2}$

Indonesia's entry into the category of countries affected by terrorism, is inseparable from the powerlessness of the state in stemming the spread of radical ideas of terrorism in society. Broadly speaking, the pattern of the spread of radical terrorism can be carried out through various available channels, such as (a) indoctrination through family relations, whether by marriage, kinship or through the main family. (b) indoctrination by direct communication through friendships, discussions and propaganda. (c) indoctrination through educational institutions both at Islamic boarding school (pesantren), schools and at the university level, (d) print and electronic mass media such as books, magazines, radio pamphlets, and

${ }^{1}$ The development of the industrial revolution 4.0 is supported by five technologies, namely artificial intelligence, internet of things, human-machine interface, robotics and sensor technology, and three-dimensional (3D) printing technology.

${ }^{2}$ Kompas.com, Indonesia peringkat 38 dari 138 Negara yang Terdampak Terorisme: Source https://nasional.kompas.com/read/2020/01/23/14051581/indonesia-peringkat-ke-35-dari-138negara-yang-terdampak-terorisme. 
TV. In fact, along with the development of the internet of things, the use of the internet through social media platforms such as Twitter, Facebook, WhatsApp etc. is a common and effective method of spreading radical-terrorism understandings used today. ${ }^{3}$

Through an internet connectivity, radical-terrorism groups are adept at utilizing information technology in framing various economic, political, and cultural issues into religious issues so as to produce an output in the form of narration or video that can be disseminated massively through social media. The results rather than framing the issue are then used as a propaganda tool to lead public opinion in acting radically both organized and acting radically themselves (self-radicalization).

This can happen because both individuals and groups can learn independently without space and time restrictions by simply following various online guidelines for radical content that has been spread, such as the nature of jihad by taking up arms, manual making and assembling bombs, instructions for using weapons, as well as assault manuals and others ${ }^{4}$ so that new facts emerge in the world of global terrorism, especially in Indonesia, is "self-radicalization". In simple terms, the writer defines self-radicalization as a new form of radicalism by spreading terror amid society without any direct connection with certain radical/terrorist groups or networks (acting radical themselves).

In line with the explanation above, Indonesian National Police Commissioner General Suhardi Alius, as the Head of the National Counterterrorism Agency (BNPT), stated that by his shrewdness in utilizing information technology, there has been a metamorphosis of the recruitment and cadre formation of radical-terrorism groups in which the new generation of radicalterrorism groups is now sufficiently honed intensively through social media by utilizing the internet. ${ }^{5}$ Therefore, the main target of the indoctrinalization of radical-terrorism understanding now is the young age group in the age range of 1640 years on the grounds that (1) the young generation today is a millennial generation who in daily life cannot be separated from internet connectivity, (2) there is a stage of psychiatric development towards maturity. This stage is a period of self-discovery so that young people will be captivated by various lighter rhetoric in fostering an ethos of struggle against oppression, injustice, and abuse of power by the government regime.

\footnotetext{
${ }^{3}$ Prof. Dr. Irfan Idris, M.A, et all., 2017, Analisis Isu Kontemporer Modul Pelatihan Dasar Calon CPNS, Lembaga Administrasi Negera RI, Jakarta, p. 68-69.

${ }^{4}$ Prof. Dr. Irfan Idris, M.A, et all., 2017, Analisis Isu Kontemporer, h. 68-69.

${ }^{5}$ Kompas.com, Kepala BNPT Ungkap Pola Rekrutmen Teroris Berubah karena Internet, https://nasional.kompas.com/read/2016/09/06/07192151/kepala.bnpt.ungkap.pola.rekrutmen.te roris.berubah.karena.internet accessed on June 28, 2019.
} 
The above argument then gets justification in Indonesia, in addition to various acts of terror carried out by radical-terrorism groups in the country, there are also Indonesian citizens who are willing to leave their motherland and choose to join radical groups of terrorism abroad. In the case of Indonesia, certainly no one can deny that since the regime of Suharto collapsed, various acts of terrorism were more prevalent and colored the dark side of this nation's journey. For example, in the regime of Megawati Sukarno Putri, suicide bombings in Bali had occurred in 2002 (Bali Bomb I) and in the JW Marriot Hotel (Jakarta) in 2003. In the regime of Susilo Bambang Yudhoyono (SBY), suicide bombings occurred at the Australian Embassy (2004), Bali Bomb II (2005), and the Ritz-Carlton Hotel bombing (2009). In Jokowi's era, suicide bombings occurred on Jl. M.H. Thamrin, Jakarta in 2016 and is known as the Sarinah bombing. ${ }^{6}$

As for terrorism cases abroad, there are hundreds or even more than a thousand Indonesian citizens who choose to be part of a foreign terrorist fighter and join a network of radical-terrorism groups such as the Islamic State of Iran and Syria (ISIS). Then in 2019, after the collapse of the ISIS group in Syria and Iraq, the issue of Indonesian citizens who joined ISIS then became a public concern in the country. Based on information from various sources mentioned that in the middle east refugee camps there were approximately 689 Indonesian citizens who were members of the Islamic State of Iraq and Syria (ISIS) group hoping to Joko Widodo so that they could be returned to Indonesia. ${ }^{7}$ However, the hope of the former ISIS Indonesian citizen did not get a good response by President Joko Widodo. In fact, in February 2020, for reasons of internal security, the government has taken a firm stance to reject their return and consider them to no longer be citizens of Indonesia. But on the other hand, for legal and humanitarian reasons there are also parties who consider the need to repatriate these ex-ISIS members to be included in the government's de-radicalization program and to be legally processed in Indonesia.

Terrorism observer from Universitas Malikussaleh Lhokseumawe Aceh, Al Chaidar, said that ex-ISIS citizens need to be repatriated on the basis of humanity,

${ }^{6}$ Examples of terrorist acts are just a few of the acts of terrorism that have occurred in each government regime and for the two previous presidents, B.J Habibie government also did not escape the terror bombing that occurred twice, while the Abdurahman Wahid (Gusdur) regime occurred at least twelve bomb terror acts and targeted several places such as houses of worship, Philippine Embassy building, Attorney Building, Campus of Universitas Darma Agung, Jakarta Governor's Office, Omni Batavia Hotel, etc.

${ }^{7}$ The latest data based on the statement of the Minister of Justice and Human Rights, Yasonna Laoly, in February 2020, stated that there were 1,276 former ISIS Indonesian citizens who were abroad. Source: https://www.cnnindonesia.com/nasional/20200225163222-20. 477996/yasonna-data-terbaru-ada-1276-wni-eks-isis-di-luar-negeri, accessed on July 8, 2020. 
because the majority of ex-ISIS citizens are women and children who are victims of ISIS propaganda and victims of male power relations in the family so that they need to be saved. In addition to humanitarian reasons, it is also related to citizenship reasons, that Indonesian citizens who are members of ISIS are still domiciled as Indonesian citizens, because they are considered to have not lost their citizens due to the absence of a court decision regarding the loss of citizenship status. Likewise, the former Chief Justice, Gayus Lumbuun, reminded the government to address the issue of former ISIS Indonesian citizens by continuing to follow legal procedures. Therefore, based on the description above, it is necessary to do An Analysis of Jokowi's Policy in Refusing the Return of Former ISIS Foreign Terrorist Fighters Indonesian Citizens so that the people can understand and assess the threats that can be caused by the return of former ISIS Foreign Terrorist Fighters in the country.

\section{RESEARCH METHOD}

This research is a normative-empirical legal research, which is a study of law whose study of statutory provisions in connection with the legal basis of banning Indonesian citizens as an Ex-ISIS Foreign Terrorist Fighters or former ISIS terrorist cross-border and connected with the reality of network development and the pattern of ISIS terrorist movements occurring in the field (in concreto), especially in Indonesia. The research applied the library research method which is analytical descriptive to explain clearly and systematically the subject matter. The type of data used is secondary data that the author obtained from various library materials. The secondary data referred to consists of primary and secondary legal materials. The main legal material in the form of Immigration Law and Government Regulation No. 21 of 2013 concerning Regulations for Implementing the Immigration Law. While secondary legal materials used can be in the form of research reports, books, articles, internet, newspapers including UN Security Council Resolutions related to global terrorism organizations.

\section{DISCUSSION}

\section{Basis of Banning Indonesian Citizens with Foreign Terrorist Fighter Status in} Indonesia

The issue of the repatriation of Indonesian citizens (WNI) who had been part of ISIS, was addressed by President Joko Widodo by taking a firm stance that in cases of problematic issues such as this the state chose to reject the return of Indonesian citizens with the status of foreign terrorist fighter of ISIS. Although this policy was taken and considered contrary to humanity, but this decision is 
considered appropriate when viewed from the aspect of national security as mandated in the opening of the 1945 Constitution that is protecting all the people of Indonesia. According to the Coordinating Minister for Politics, Law and Security, Mahfud MD, the state has the responsibility to protect its citizens both inside and outside the country, but in this case the country prioritizes the security and safety of 267 million people of Indonesia rather than repatriating 689 ex-ISIS members who are still in refugee and labeled as a foreign terrorist fighter or border crossing terrorist.

In the law, the state's rejection of someone who wants to enter Indonesia is known as "deterrence". The rules regarding this deterrence can be found in Article 98 Paragraph 1 of Law No. 6 of 2011 concerning Immigration which gives authority to the government in this case the minister to conduct deterrence and furthermore, in Paragraph 2 it is also stated that the competent official can ask the minister to do the deterrence. Therefore, in practice, based on the Immigration Law, the deterrence of people entering Indonesia must be carried out by a designated minister or an immigration official who is appointed and stipulated by a written decision. However, the issue of deterrence will certainly be a debatable issue if it refers to the definition of deterrence under the Immigration Law. Based on Article 1 Paragraph 29 of the Immigration Law, it is stated that basically the deterrence is a prohibition against foreigners entering Indonesian territory for immigration reasons. Whereas in this case, those who will be banned from entering Indonesian territory are Indonesian citizens who have been involved with ISIS.

Based on the author's opinion, this deterrence can only be aimed at ex-ISIS members residing abroad by extending the interpretation of foreigners. Because by joining into the Islamic State of Iraq and Syria (ISIS) terrorist group, these Indonesian citizens can loss their citizenship as regulated in Article 23 letter d, which is included in the foreign army service without prior permission from the President. Indeed, there has been a debate whether being part of ISIS can be classified as "foreign army service". In my opinion, ISIS is indeed not a country that receives recognition of sovereignty, but ISIS is a militia group that is trying to establish a country by using force to replace and overthrow legitimate governments in Iraq and Syria. Apart from that, Indonesian citizens who have joined ISIS have also burned passports and of course before their passports are destroyed, they have voluntarily taken an oath or pledge of allegiance to ISIS. We can also conclude that it meets the criteria of Article 23 Letter $f$ which states that Indonesian citizens lose their citizenship because they voluntarily took an oath and/or promised to be loyal to a foreign country or part of that foreign country. From the two norms provisions, the authors conclude that Ex-ISIS members no longer recognize themselves as 
citizens and have status as stateless (someone without citizenship). ${ }^{8}$ Therefore, the relevant ministries must also conduct studies and in-depth searches of ex-ISIS members who are in evacuation to have valid data that can be used as a basis for the government in conducting administrative legal processes so that the President can immediately determine the list of names of ex-ISIS Indonesian citizens who have lost their citizenship status.

In addition, the technical rules for implementing deterrence are clarified in Government Regulation (PP) No. 21 of 2013 concerning Regulations for the Implementation of the Immigration Act. In this regulation, based on the provisions of Article 263 Paragraph 2 letter (a) it is stated that a person's involvement in organized transnational crime is one of the reasons for the deterrence. ${ }^{9}$ Then, whether ISIS can be categorized as part of transnational crime. In an article titled "Strategies in Facing Terrorism-ISIS Radicalism" compiled by the National Counterterrorism Agency (BNPT), ISIS is categorized as part of a terrorist group. It was explained in the article that after Saddam Husain's regime in Iraq stepped down and the government was controlled by Shiite groups, it caused dissatisfaction from some parties so that a new movement was born from the power of the Iraqi national mailing list founded by Al Zarqawi. As the founder of this movement, Zarqawi originally came from the Al Qaeda Network which had taken oath of allegiance and declared itself as part of Al Qaeda under the leadership of Osama Bin Laden. While Al Qaeda itself by the United Nations was considered as an international terrorist network.

Shortly afterwards, in 2014 under the command of Abu Bakar al Baghdadi this militia group declared itself as the Islamic State of Iraq and Syria (ISIS) with the territorial power covering parts of Iraq and Syria. The strength of this militia then metamorphosed into a major force and shocked the world after able to conquer Iraq's second largest region, Mosul. In addition, due to its influence and propaganda, ISIS is able to embrace terrorist groups such as Boko Haram to pledge allegiance to it and influence radical figures in Southeast Asia. As a new terrorist force, the appeal of ISIS propaganda is not limited to the Middle East and Southeast Asia, but its influence extends far into Europe and America. Even from

${ }^{8}$ Law Number 2 of 2017 concerning Citizenship of the Republic of Indonesia.

${ }^{9}$ In addition to these reasons, deterrence of a person can also be done based on other immigration reasons, such as (a) known or suspected involvement in organized transnational crime; (b) show hostility towards the Government of Indonesia or commit acts that defame the nation and state of Indonesia; (c) is suspected of committing acts that are contrary to the security and public order, decency, religion, and customs of the Indonesian people; (d) use fake or forged passports to obtain a Visa or Stay Permit to enter and be in Indonesian Territory; and/or (e) are subject to Immigration Administrative Action in the form of Deportation from Indonesian Territory (see Article 263 Paragraph 2 of Government Regulation Number 31 of 2013). 
2011 to October 2014, an estimated 15,000 people from various parts of the world have joined ISIS. ${ }^{10}$

Based on this description, it is clear that ISIS is part of a network of terrorist groups whose combatants come from crossing national borders (foreign terrorist fighter), so we can categorize former ISIS members as transnational crimes. This is in line with the scope of transnational crime as the explanation of Article 13 Paragraph 1 Letter (g) of Law no. 6 of 2011 concerning Immigration, that included in the scope of international crimes and transnational crime is terrorism, human smuggling, money laundering, human trafficking, as well as narcotics and psychotropic substances. In addition, the UN organization itself has officially declared that ISIS is a terrorist organization. This statement was stated in UN Security Council Resolution No. 1267 of 1999 updated No. 1989 in 2011 and UN Security Council Resolution No. 2179 August 15, 2014 where ISIS/ISIL and Jabatul Nushra were declared terrorist organizations. Whereas in Indonesia, ISIS is categorized as a terrorist organization based on the stipulation of the Central Jakarta District Court No. 11204/Pen.Pid/2014PN.JKT.PST on October 11, 2014 and List of suspected Terrorists and Terrorist Organizations Number: DTTOT/2723/XI/2014 dated November 20, 2014, ISIS was established as a terrorist organization in Indonesia.

\section{ISIS and Threat of Terrorism in Indonesia}

Understanding the legal basis for blocking ex-ISIS citizens to return to Indonesia, we also need to examine security reasons that are the basic considerations of President Joko Widodo in rejecting the return of ex-ISIS members. Many parties consider this decision as the right decision to provide protection against citizens, especially those who are in the country. Even Willy Aditya, one of the members of the Indonesian Parliament from the Nasdem fraction, responded critically to the discourse of repatriation of ex-ISIS members. He even warned the government to be keen to see this issue as part of ISIS propaganda under the guise of humanity. ${ }^{11}$ This concern is important to understand, because the ISIS group's network is like an "iceberg phenomenon", from the aspect of ISIS's territorial and military dominion, it has yet to be completely conquered. As an ideological network, military defeat and the death of their leader Abu Bakar al-Baghdadi gave birth to new cells of clandestine

${ }^{10}$ Badan Nasional Penanggulangan Terorisme, Strategi Menanggulangi Paham Radikalsime Terorisme-ISIS, Jakarta, Belmawa, 2016, p. 3.

${ }^{11}$ Medcom.id, Isu Pemulangan WNI Eks ISIS Propaganda Berkedok Kemanusiaan. Source: https://www.medcom.id/nasional/politik/ObzMGGIN-isu-pemulangan-wni-eks-isis-propagandaberkedok-kemanusiaan, accessed on June 11, 2018. 
terrorism. ${ }^{12}$ They are also well organized through internet connectivity. In fact, the authors argue that even in conflict areas, this network of terrorist cells may infiltrate as part of refugees to be confined to refugee camps in the Middle East or in crossborder cases, such as in Indonesia some ISIS sympathizers still remain in the Indonesian territory while remaining share with the community and activities in general. However, if they get a signal from their group, these terrorism cells will later be martyred in carrying out suicide bombings either in groups or working independently (self-radicalization).

ISIS as an international terrorist network declared in 2014 has attracted many people from various parts of the world to join. In 2015, for example, based on intelligence reports as quoted by New York Time, said that every month there are around 1,000 people joining ISIS and coming from various parts of the world. ${ }^{13}$ Meanwhile, ISIS sympathizers from Indonesia, according to estimates from the National Counterterrorism Agency (BNPT), there are approximately 600 Indonesian citizens who have joined ISIS. ${ }^{14}$ Meanwhile, ISIS sympathizers from Indonesia, according to estimates from the National Counterterrorism Agency (BNPT), there are approximately 600 Indonesian citizens who have joined ISIS. The three stages are first, indoctrination is carried out by evoking the nostalgia of the triumph of Islam in the era of Islamic caliphate and collapse. Second, build morale. After the nostalgic stages of the triumph and collapse of Islam, the next stage is to display the spectacle of Jewish and American atrocities against Muslims and Muslim countries, the US invasion of Iraq and Afghanistan, and the Guantanamo prison. And in the third stage is conveying dalil, namely conveying the arguments in the Holy Quran and the hadith according to their understanding to cause the desire to strive for jihad. ${ }^{15}$ Such as the use of a half-proof dalil about fighting the infidels.

Not much different from Abdul Rahman Ayub, Peace Generation director, Irfan Amale, argued that to recruit someone to be part of a radical-terrorism group can be done in various ways, namely (1) the use of historical narratives, where historical education does not only arouse knowledge/wisdom in seeing an event/conflict but can also arouse a grudge that is able to ignite emotions to reclaim

\footnotetext{
${ }^{12}$ The term clandestine refers to a network of terrorism that is secretive, discreet and or conducts underground movements.

${ }^{13}$ https://www.cnnindonesia.com/internasional/20151229081519-120-100848/tahun2015-isis-panen-pengikut-dari-puluhan-negara, accessed on June 15, 2020.

${ }^{14}$ https://www.cnnindonesia.com/nasional/20150422153247-12-48476/bnpt-sudah-ada600-wni-yang-diduga-bergabung-isis?, accessed on June 15, 2020.

${ }^{15}$ Denny Armhandhanu, Tiga Tahap Pola Cuci Otak Kelompok Radikal, https://www.cnnindonesia.com/internasional/20150324141129-106-41446/tiga-tahap-pola-cuciotak-kelompok-radikal accessed on June 28, 2019.
} 
the glory of the past, and this is what is meant to evoke the nostalgia of the triumph of Islam. (2) The use of political narratives, which view that there has been an imbalance and injustice exhibited by the authorities which then targets young people to be called to do jihad. (3) Psychological narratives, which classify violent actors as heroes, (4) instrumental narration that views violence as a solution to solve problems. The use of political, psychological, and instrumental narration can be grouped as stages to build fighting spirit and (5) religious narratives that use verses to recruit new members of the group and are categorized as a stage of judgment.

After the defeat of ISIS, government data until February 2020 stated that there were 1,276 Indonesian citizen ex-ISIS members residing in refugee camps in the Middle East. But the government has difficulty in having real data on how many Indonesians have been exposed to ISIS, both inside and outside the country. The absence of real data of citizens exposed to ISIS is one of the main factors that raises government concerns in repatriating ex-ISIS citizens. In addition, it is also feared, lest some of the ex-ISIS Indonesian citizens who were repatriated later become part of terrorism sleep cells, which can recruit new members or move and affiliate with terrorism cells in the country to commit terror in various regions in Indonesia.

Furthermore, by looking generally at the fact of the success of the indoctrination of terrorism networks in recruiting new members which led to various acts of terrorism in Indonesia, then in the period of 2016-2019 (after the ISIS declaration) the results of the writer's search show that in addition to suicide bombings, terror was also carried out by means of carrying out direct attacks on individuals or community groups as targets, whether as state officials, the police officers or ordinary civilians. In addition, in several acts of terror, especially those carried out by the ISIS network, it has shown a new phenomenon where women and children are involved as part of suicide bombings. For more details, the following describes several acts of terrorism that occurred in Indonesia in 20162019.

In 2016, suicide bombings occurred in Jakarta and in Surakarta, Solo. In Jakarta, suicide bombings occurred on January 14, 2016 precisely at the Starbuck coffee shop. One of the bombers was Ahmad Muhazan. While in the Solo area, a suicide bombing took place at the Surakarta Police Headquarters, Solo on July 5, 2016. In this incident, one police officer was injured and the bomber, Nur Rohman, was killed while carrying out his action. In 2017, Jakarta was again shaken by a suicide bombing on May 24, 2017 in Kampung Melayu. In this incident, 3 police officers were killed. In 2018, an act of terrorism occurred in the Surabaya city and this event showed a new fact of the development of terrorism in which the 
perpetrators were one family by involving women and children to carry out suicide bombings in three different places.

First, a suicide bomb attack occurred at the Santa Maria Catholic Church on Sunday, May 13, 2018 at 06.30 WIB. The suicide bomber was carried out by Yusuf (18 years old) and his younger brother, Firma (16 years old). Both are children of the couple Dita Oepriarto and Puji Kuswati. After a while, a suicide bomb attack occurred again at the Indonesian Christian Church (Gereja Kristen Indonesia), at 07.15 with the executor was Puji Kuswati (Dita's wife). In this attack, Puji Kuswati also included his two children, Firman (12 years old) and Famela (9 years old). In the third attack, a new suicide bomb was carried out by Dita Oepriarto at the Central Pentecostal Church (Gereja Pantekosta Pusat) in Surabaya at 07.53 WIB. In addition to the suicide bombing carried out by Dita Oepriarto's family, the suicide bombing was also carried out by the Tri Murtiono family at Surabaya Police Station. In carrying out the action, Tri Murtiono also involved his wife Tri Ernawati and their three children. However, in this incident, one of his children died and two survived. Furthermore, in 2019, suicide bombers again targetted police officers. Rofik Asharuddin, who was exposed to radical terrorism through the internet, began learning to assemble bombs and then carried out his actions at the Security Post of Sukoharjo Police Station at the Kartasura monument, Sukoharjo.

Aside from suicide bomb attacks carried out by terrorism networks, there are also other forms of terror in the form of direct attacks against state officials or members of the police force. This method of attack is nothing but the implementation of the understanding conveyed by ISIS leader Abu Bakar al Baghdadi that capital is a sharp weapon and an ordinary target, ISIS sympathizers have been able to join the jihad. ${ }^{16}$ In line with this message, and to show its existence, in 2018, a number of terrorist prisoners then rioted and took hostage members of the police at the Detention Center of Brimob Command Headquarters in Kelapa Dua, Depok, West Java. In this action, five Brimob Police Officers Brigade were killed. Subsequently in 2019, Wiranto who still served as Coordinating Minister for Political, Legal and Security Affairs was stabbed in Pandeglan, Banten. The culprit was carried out by Syahril Amansyah (Abu Rara) with his wife Fitri Andriana. In the case of Wiranto, if seen from the pattern or form of terror At the time of acts of terror in the form of stabbing, it is commonly used by terror groups abroad, as was the case in France in 2016 where a police officer and his wife were killed stabbed by Larossi Abballah in Magnanville, Paris,

${ }^{16}$ https://www.cnnindonesia.com/internasional/20191010152558-134-438450/isis-danrentetan-aksi-teror-penikaman-di-dunia. 
the perpetrators were followers of ISIS. In June 2019 in Chechnya, one of the police officers was also killed stabbed near the residence of the Chechen leader, Ramzan Kadyrov, and on this occasion ISIS also claimed responsibility.

As explained above, there are new facts in which women and children have begun to be involved in various acts of terror in Indonesia, especially suicide bombings. Roby Kholifah, Director of The Asian Muslim Action Network (AMAN) suggested 4 factors driving women's involvement in various acts of terror. First, the defeat of ISIS in various battle fields which indicates that male extremists are no longer able to carry out their actions fully. Accordingly, there is a space in providing opportunities for women extremists to jihad. Secondly, the success of ISIS propaganda has made women extremist groups more numerous and solid, even more militant. According to him, female extremists did not prepare themselves, but their conditions were ready. This is happening no other than that within the family sphere the main role for doctrining children is in women. So that the indoctrinalization of children is from the mother, not the result of doctirinisation of the father. Third, the influence of information technology, which has an impact on the pattern of recruiting terrorist networks that is intensely carried out through social media. And fourth, there is no gender perspective approach in counteracting acts of terrorism.

Various acts of terrorism that occurred and the existence of extremist women who involved children in acts of terrorism in the field. In a sociological perspective, it takes a process or stages of interaction that are passed so that a person becomes physically and mentally ready to carry out a suicide bombing. Because based on its type, radical groups that develop in Indonesia can be classified into several types. First is the Radical Idea. This group has radical ideas but does not use violence in realizing it. Secondly, Radical Militia, which is a radical group formed by communal conflict, but still recognizes the Republic of Indonesia. Third, Radical Separatism. This is a group that promotes rebellion/separatism by conducting various confrontations with the government. This group is trying to break away from the Republic of Indonesia. Fourth, Radical Gangsterism which is a group that implements acts of violence against all forms of immunity, but still recognizes Indonesia. Fifth, Radical Terrorism, a group that promotes violence and causes widespread fear in society. This group no longer recognizes Indonesia and seeks to replace the state ideology. ${ }^{17}$

Based on the classification of radicalism above, then of course there are stages of social interaction that someone has gone through so that they fall into the

${ }^{17}$ Prof. Dr. Irfan Idris, M.A, et al., 2017, Analisis Isu Kontemporer Modul Pelatihan Dasar Calon CPNS, Lembaga Administrasi Negera RI, Jakarta, p. 69. 
category of radical-terrorism groups. Therefore, the researcher about political violence, Noor Huda Ismail, revealed that there are five stages of social interaction that can involve a person so that it turns into a terrorist. The first stage, a person or a group of people have a strong belief that they are victims of injustice. Upon this view, they then tried to find a solution. When a solution is not found, they try to move up to the next stage. In the second stage, for the injustices they face, they try to identify external factors that are considered to be responsible. In this identification process, they believe that external factors have an agenda to systematically destroy them. There are two important implications of this conclusion, firstly, they are categorized as bad people so that the use of violence against them can be justified. Second, this group of evil people is then labeled as "evil" (devil) which means to position them as sub-humans (no longer human). Those who gather on the second step then mingle with those who have the same feelings. They then direct their anger towards the common enemy.

In the third stage, the group's moral bond is formed. At this stage there were discussions carried out among them clandestinely how to resist the injustices that befall them so that before engaging in physical violence activities against the enemy, physical and mental readiness needs to be prepared. Leaders continue to emphasize the importance of loyalty to the organization and try to isolate themselves from the community. In the fourth stage, the new recruitment process actually takes place. At this stage, terrorists divide the world into two contradictory parts namely us versus them. They only know people in their cells, they do not recognize other cells. In the fifth stage, training for terror attacks is given to members who are chosen to be trained. At this stage, the opportunity or opportunity to go back down is closed and the leader treats them with special treatment. For example, they are given the opportunity to see their families or leave messages for them as did Dwi Dwi Permana. ${ }^{18}$

\section{CONCLUSION}

Industry 4.0 which is supported by the concept of the Internet of Things (IoT) has a significant impact on the recruitment patterns of new members of terrorist networks in the world. Besides changing recruitment patterns, it also influences the ways in which members of terrorist groups spread fear in the community. Based on the results of the author's research that after the declaration of the Islamic State of Iran and Syria (ISIS), there were at least 689 foreign terrorist fighter or terrorists crossing from Indonesia, who were to be repatriated in 2019. Even the latest government data in February 2020, there are 1,276 former ISIS

\footnotetext{
${ }^{18}$ Noor Huda Ismail, The Jakarta Post Youth Speak" volume 2, September 2009.
} 
citizens who are in refugee camps in the Middle East. However, President Jokowi took a firm stance by rejecting the plan to return the ex-ISIS Indonesian citizens on the grounds of prioritizing providing security to its citizens in the state than citizens who have joined the ISIS network. The legal basis that can be used is Article 98 Paragraph 1 of Law No. 6 of 2011 concerning Immigration which gives the minister the authority to deter and Paragraph 2 that the authorized official may ask the minister to deter. Then, Article 263 Paragraph 2 letter (a) Government Regulation No. 21 of 2013 concerning Regulations for the Implementation of the Immigration Act, mentions one of the reasons for the banning is because of one's involvement in organized transnational crimes such as terrorism. In terms of security, the ban is carried out based on security factors, namely the factor of clandestine terrorism cells and can spread terror anywhere and anytime in Indonesia, if it has received a signal from a group. In addition, acts of terrorism in Indonesia also show a new phenomenon, with the increasing involvement of women and children in one family to carry out suicide bombings. There is also a new pattern that is carried out, namely attacks carried out directly by targeting state officials, the police officers and ordinary citizens.

\section{REFERENCES}

Al-Qardhawi, Yusuf. (1406 H). al-Shahwah al-Islamiyah bayn al-Juhud wa al-Tattarruf. Cairo: Bank alTaqwa.

Badan Nasional Penanggulangan Terorisme, Strategi Menanggulangi Paham Radikalsime Terorisme-ISIS, Jakarta, Belmawa, 2016

CNNIndonesia.com, Yasonna, Data Terbaru ada 1276 WNI Eks ISIS di Luar Negeri https://www.cnnindonesia.com/nasional/20200225163222-20477996/yasonna-data-terbaru-ada-1276-wni-eks-isis-di-luar-negeri, accessed on June 8, 2020.

, BNPT, Sudah Ada 600 WNI yang DIduga Bergabung ISIS, sumber: https://www.cnnindonesia.com/nasional/20150422153247-12-

48476/bnpt-sudah-ada-600-wni-yang-diduga-bergabung-isis?, accessed on June 15, 2020

ISIS, dan Rentetan Aksi Teror Penikaman di Dunia, https://www.cnnindonesia.com/internasional/20191010152558-134-

438450/isis-dan-rentetan-aksi-teror-penikaman-di-dunia

, Kepala BNPT Ungkap Pola Rekrutmen Teroris Berubah karena Internet, https://nasional.kompas.com/read/2016/09/06/07192151/kepala.bnpt.u

ngkap.pola.rekrutmen.teroris.berubah.karena.internet accessed on, May 28, 2020 
Tahun 2015 ISIS Panen Pengikut dari Puluhan Negara. Source: https://www.cnnindonesia.com/internasional/20151229081519-120-

100848/tahun-2015-isis-panen-pengikut-dari-puluhan-negara, accessed on June 15, 2020

Tiga Tahap Pola Cuci Otak Kelompok Radikal, https://www.cnnindonesia.com/internasional/20150324141129-10641446/tiga-tahap-pola-cuci-otak-kelompok-radikal accessed on May 282019

Government Regulation No. 21 of 2013 concerning Regulations for Implementing the Immigration Law.

Irfan Idris, et al, 2017, Analisis Isu Kontemporer Modul Pelatihan Dasar Calon CPNS, Lembaga Administrasi Negera RI, Jakarta.

Kompas.com, Indonesia Peringkat ke 35 Dari 138 Negara yang Terpapar Terorisme. Sumber

https://nasional.kompas.com/read/2020/01/23/14051581/indonesiaperingkat-ke-35-dari-138-negara-yang-terdampak-terorisme accessed on May 28,2020

Law No. 6 of 2011 concerning Immigration

List of suspected Terrorists and Terrorist Organizations Number: DTTOT/2723/XI/2014 dated November 20, 2014; ISIS has been designated as a terrorist organization in Indonesia.

Mbai, Ansyaad. (2016). Urgensi Penguatan Undang-Undang Terorisme, makalah disampaikan pada Seminar tentang Pemberdayaan Lembaga Negara dalam Penanganan Terorisme di Indonesia, Sekolah Tinggi Hukum Militer “AHM-PTHM”, Jakarta, 8 Maret 2016.

Medcom.id, Isu Pemulangan WNI Eks ISIS Propaganda Berkedok Kemanusiaan. Sumber: $\quad$ https://www.medcom.id/nasional/politik/ObzMGGIN-isupemulangan-wni-eks-isis-propaganda-berkedok-kemanusiaan, accessed on June 11, 2018

Noor Huda Ismail, The Jakarta Post Youth Speak” volume 2, September 2009

UN Security Council Resolution No. 1267 of 1999 updated with No. 1989 of 2011

UN Security Council Resolution No. 2179 dated August 15, 2014 which stated ISIS/ISIL and Jabatul Nushra were declared terrorist organizations.

Verdict of the Central Jakarta District Court No. 11204/Pen.Pid/2014PN.JKT.PST on October 11, 2014 